\title{
Parental control mechanisms and their reflection on identity styles of Turkish adolescents ${ }^{1}$
}

\author{
Hacer Nermin Çelen ${ }^{2}$ \\ Maltepe University, Istanbul, Turkey \\ Muharrem Ersin Kuşdil \\ Uludag University, Bursa, Turkey
}

\begin{abstract}
Research has shown that authoritarian parents limit their children's freedom of expression and monitor their children's behavior according to their rules. Children of authoritative families tend to have high self-esteem and refer to internalized norms. Parenting is a cultural product. In this study the model presented is limited in the sense that it does not consider the cultural diversity. We must evaluate the identity not only with perceived parenting style but also within the socio-cultural context. The present study explored the relationships between identity styles and perceived parenting control patterns in late adolescents. Responses of 402 Turkish university students to the Berzonsky's Identity Style Inventory were factor-analyzed, and patterns of correlations between four identity statuses, Steinberg's Authoritative Parenting Scale, and Kağıtçıbaşı's Authoritarianism Scale and parental education were examined. The findings are discussed in relation to ways of incorporating the cultural context into the study of identity development.
\end{abstract}

Keywords: identity, adolescents, parents, sociocultural factors, cross cultural differences.

\section{Mecanismos de controle parental e sua influência no estilo identitário de adolescents turcos}

\begin{abstract}
Resumo: Pesquisas têm evidenciado que pais autoritários restrigem a liberdade de expressão de seus filhos e orientam o comportamento deles de acordo com suas normas. Crianças de famílias autoritárias tendem a apresentar elevada auto-estima e responder a normas internalizadas. A paternagem é um produto cultural, o modelo aqui apresentado é limitado por não considerar a diversidade cultural. Devemos avaliar a identidade não apenas como modelo parental percebido, mas também como parte do contexto sócio-cultural. O presente estudo explorou as relações entre modelos identitários e padrões de controle parental percebidos em jovens adultos. As respostas de 402 estudantes de uma universidade turca ao Berzonsky's Identity Style Inventory foram submetidas à análise fatorial. Padrões de correlação entre quatro status de identidade, Steinberg's Authoritative Parenting Scale, Kağıtçıbaşı 's Authoritarianism Scale e educação parental foram examinados. Os resultados são discutidos em relação ao modo de incorporação do contexto cultural no estudo do desenvolvimento da identidade.
\end{abstract}

Palavras-chave: identidade, adolescentes, pais, fatores socioculturais, diferenças interculturais.

\section{Mecanismos de control parental y su influencia en el estilo de la identidad de jóvenes turcos}

\begin{abstract}
Resumen: Investigación tiene evidenciado que los padres autoritarios restringen la libertad de expresión de sus hijos y orientan el comportamiento de ellos de acuerdo con sus normas. Niños de familias autoritarias tienden presentar elevada autoestima y responder a normas internalizadas. Lo control de los padres es un producto cultural, el modelo aquí presentado es limitado por no considerar la diversidad cultural. Debemos evaluar la identidad no apenas como modelo parental percibido, más también como parte del contexto socio-cultural. El presente estudio exploro las relaciones entre modelos de identidades y padrones de control parental percibidos en jóvenes adultos. Las respuestas de 402 estudiantes de una universidad Turca al Berzonsky's Identity Style Inventory fueran submetidas al analice factorial. Padrones de correlaciones entre cuatro status de identidad, Steinberg's Authoritative Parenting Scale, Kağıtçıbaşı's Authoritarianism Scale y educación parental fueran examinados. Los resultados son discutidos en relación al modo de incorporación del contexto cultural en el estudio del desarrollo de la identidad.
\end{abstract}

Palabras clave: identitad, adolescente, padres, factores socioculturales, diferencias interculturales.

Students of the concept of identity have had some problems in defining this concept; therefore, they prefer to explain it by highlighting its several core characteristics, such as sameness, continuity, constancy, uniqueness. A $19^{\text {th }}$ century psychologist, William James, was the first scholar

1 Paper presented at the $10^{\text {th }}$ Congress of European Adolescent Research Association, May 2006. This project was supported by the Research Fund of the University of Uludag.

2 Endereço para correspondência:

Hacer Nermin Çelen. Maltepe University, Egitim Fakultesi. Basibuyuk Kampusu, Maltepe, 34857. Istanbul, Turkey. E-mail: nermincelen@ yahoo.com to put forward continuity and uniqueness characteristics of identity into psychological literature (Shaffer, 1994). He also stated that there was a relationship between subjective self and identity, which constitutes the basic tenet of a position taken by today's psychologists (Duvall \& Wicklund, 1972). Erikson (1950, 1968) shouldered the responsibility of introducing the concept of identity to the areas of clinical and developmental psychology.

According to Erikson, ego identity is the expression of the self position of an individual. He explained identity development in terms of the notion of psycho-social stages. These stages are the outcomes of conflicts between the 
demands of biological maturation and social expectations directed towards the individual. Experiencing such conflicts in these stages leads the individual to an imbalanced position. Imbalance should be overcome by constructing a new schema or accommodation behavior. In each stage, individuals form a new configuration of their psycho-social lives.

During adolescence, individuals review old patterns or configurations and replace their schemata partly consciously, partly unconsciously (Hart, Maloney, \& Damon, 1987). This process helps individuals to achieve the continuity and sameness in their lives. Identity depends on the past and also on the future. During pre-adolescence, one perceives the physical and social contexts differently than they would during post-adolescence, due to cognitive development. During adolescence, one has enough social experience and cognitive abilities to reshape ones' identity and may accommodate new social experience (Rowe \& Marcia, 1980). New schemata on family, friendship, career and political issues are expected to be constructed in this period (Bosma, 1992; Enright \& Deist, 1979). When an adolescent is constructing new schemas, she/he also senses the continuity and sameness. One should make a synthesis of the roles centered on the objective self with the subjective self to construct a new portrait pattern about oneself. Obviously, this is not a smooth process, because there is always a conflict between social expectations and demands of the cognitive and biological maturation processes. Erikson (1968) named such conflicts as a "crisis". According to him, after experiencing a crisis, individuals reach one of the different poles such as Achieved Identity and Role Confusion. The person, who achieves identity, experiences a crisis and finally makes a commitment, but others who may or may not experience crisis, do not make any commitment.

Marcia (1966) also defines identity as Erikson does. According to him, "identity is hypothetical - intra-psychic structure". This structure can be evaluated by the help of psycho-social commitments. He explained identity by using two concepts: exploration and commitment. Exploration is relevant to crisis. It represents the cognitive and behavioral differentiations. Commitment, on the other hand, is a decision making process. Marcia proposed four identity statuses: (a) Achieved Identity (exploration +, commitment + ); (b) Moratorium (exploration + , commitment -); (c) Foreclosure (exploration -, commitment +); (d) Diffused Identity (exploration -, commitment -). On the experiential level, identity refers to a subjective experience. He explained his views as follows:

One feels that he has some continuity with his past, some meaning in the present and some direction for the future. He feels that he has a stake in his society or in part of it. Identity also refers to objective observable behaviors. The achievement of identity ought to be manifested in commitment (Marcia, 1966, p. 552).
Berzonsky (1992b) proposed a new model for explaining the process of structuring identity statuses by using Piaget's cognitive terminology. The concepts of assimilation and accommodation occupy a pivotal position in his model. According to him, when there is a lack of awareness of identity, it refers to assimilation behavior. When an individual receives annoying inputs, an imbalanced position occurs. This helps the individual to increase his or her awareness of identity. This position is quite similar to the notion of crisis mentioned by Erikson (1968). The individual reshapes the structure of his or her identity by the help of new experiences (accommodation) until the next imbalanced situation occurs (Berzonsky, 1992b; Berzonsky \& Sullivan, 1992). The balance between accommodation and assimilation differs from person to person, which leads to individual differences in psycho-social development. According to this model, individuals perform different problem solving behaviors, decision making styles and identity processes.

There are three different identity styles in Berzonsky's socio-cognitive identity model: information-oriented, normoriented and diffuse-oriented identity styles. Informationoriented individuals are keen to details, confident and respect their own thoughts in problem solving and decision making. This style is quite similar to Moratorium and Achieved Identity statuses proposed by Marcia (1966). Informationoriented identity has a positive relationship with internal locus of control and negative relationship with authoritarianism. In this identity style the individual explores alternatives and decides on whatever is considered proper. They are aware of their individual emotions and believe that they are open to new horizons and experiences. They have liberal values, intellectual curiosity and intuition, in addition to complex cognitive schemata and consciousness.

Norm-oriented individuals try to adapt to the norms of reference persons. This identity style is equivalent to the Foreclosure identity status reported by Marcia (1966). Norm-oriented individuals do not actively search for proper information to solve a problem. They use information valued by prestigious models. Their schemata are constructed by individualized norms. These kinds of schemata lead to biased commitments and thought processes. Norm-oriented style and social identity are intertwined. It depends on internalized social expectancies and tendencies.

Diffuse/avoidant-oriented individuals are characterized by their defensive manners. They are reluctant to face problems and usually procrastinate stated wishes. External locus of control is dominant. They do not search for the best solution and proper information to solve a problem and rarely make long-term plans. They are sensitive, depressive, and have neurotic personal characteristics.

These socio-cognitive identity styles are the outcomes of psycho-social intersections. Each helps a person to develop specific perspectives. Psycho-social development is the outcome of socialization. Baumrind (1971, 1991a, 1991b) explains this process as teaching a child attitudes and manners. Baumrind divides family child-rearing styles into 
three categories according to families' responsiveness and level of requirement. These are authoritarian, authoritative and permissive styles. There is a high degree of demand and a low degree of responsiveness in authoritarian families. Children comply with the family norms without questioning values. They are usually warm and welcoming, but they do not value autonomy and independence. Authoritative families set standards to guide the development of their child . They are warm, welcoming, value autonomy and independence. The responsiveness level of permissive families is high but they have limited control over their children. Children who live in this kind of family, have low ego power strength, are irresponsible and ego-centered.

Research show that there is a positive relationship between authoritarian control systems, conformity, obedience and external locus of control. Children who have authoritative parents are more individualistic. They are self-sufficient and have higher levels of self-control, and psychologically and cognitively motivated (Baumrind, 1991a; Steinberg, Elmen, \& Mounts, 1989). Children of permissive families are irresponsible, uncontrolled, have low ego strength, and tend to be ego-centered (Lamborn, Mounts, Steinberg, \& Dornbusch, 1991).

This study is based on the findings of the relationship between child-rearing processes and socio-cognitive identity styles. It can be easily seen in samples taken from Western cultures that there is a positive relationship between authoritative families and the information-oriented identity style; authoritarian families and the norm-oriented identity style (Berzonsky \& Kinney, 1998; Berzonsky \& Kuk, 2000). Turkish society, which is currently based on traditional values, is moving towards more Western values, and is valuing individualism and relatedness (Kağıtçıbaşı, 1996a, 2005). Therefore, Turkish families can simultaneously have both authoritarian and authoritative qualities. The main hypothesis of this study is that there is a positive relationship between information-oriented identity style and authoritative and authoritarian parenting styles. The study also aims to explore the relationship between socio-cognitive identity styles and parents' educational level, gender differences.

\section{Method}

\section{Participants}

The sample of the present study consisted of 402 university students (219 females and 183 males) aged 17 to 26 years $(X=19.59, S D=1.14)$ from various departments of Uludag University. Approximately half of the parents of the participants in the present study ( $41 \%$ of mothers and $59 \%$ of fathers) were high school graduates or had higher schooling levels. Given the relatively low rates of education for Turkish women, these figures imply that the sample of the present study is limited in terms of its representativeness. However, the sample can be regarded as geographically representative as the participants were from different areas of Turkey.

\section{Instruments}

(1) Identity Style Inventory: Berzonsky's (1992a, 1993) inventory includes 40 items to measure the four identity statuses (informational, normative, diffuse/avoidant, and identity commitment). Participants rated each item on a five-point Likert scale. Table 1 presents internal reliability coefficients for each identity status. In general, these coefficients were acceptable with one exception $(\alpha=.44$ for normative status). A factor analysis of the data using principal components method with Varimax rotation showed that a number of items that were designed to measure normative status appeared to load on informational and identity commitment factors. Therefore, the findings related to normative status need to be evaluated with caution.

Table 1

Means, standard deviations, and reliability coefficients for the scales

\begin{tabular}{lccc}
\hline & Mean & SD & Alpha \\
\hline Identity Statuses & & & \\
$\quad$ Normative & 3.52 & .51 & .40 \\
Informational & 3.70 & .50 & .63 \\
Diffuse/Avoidant & 2.34 & .64 & .62 \\
$\quad$ Identity Commitment & 3.82 & .47 & .56 \\
Authoritative Parenting & & & \\
$\quad$ Psychological & 3.14 & .53 & .68 \\
$\quad \begin{array}{l}\text { Involvement } \\
\text { Autonomy Granting }\end{array}$ & 3.03 & .47 & .58 \\
$\quad \begin{array}{l}\text { Scale } \\
\text { Authoritarian }\end{array}$ & 6.16 & .80 & .69 \\
$\quad$ Parenting & .80 & 1.04 & .44 \\
\hline
\end{tabular}

(2) Authoritative Parenting Scale: Participants' perceptions towards their parents' authoritative parenting practices were assessed by using Steinberg's scale that included 18 items. Participants rated these items on a four-point Likert type scale. Steinberg differentiated two dimensions underlying such parenting practices, namely Psychological Involvement (PI) and Autonomy Granting (AG). In order to see whether this factorial structure could be obtained in responses to the Turkish version of the scale, a factor analysis using principal components method with Varimax rotation was realized. The results showed that all, but one item, loaded on the presumed factor (the exception was the item no. 3). PI factor explained $18 \%$ of the variance (Eigen value $=3.25$ ), whereas the second factor, $\mathrm{AG}$ (Eigen value $=1.77$ ), explained $9.9 \%$ of the total variance. Reliabilities for each dimension were acceptable (Table 2). By excluding the item 3, the reliability coefficient for PI increased from .63 to .68 . Nine items of the AG dimension produced coefficient of .58 . The Alpha for the total of 17 items was .69 (Steinberg \& Hill, 1978).

(3) Authoritarian Parenting Scale: Participants' perceptions towards their parents' authoritarian parenting 
practices were assessed by using 12 items of the Kağıtçıbaşı's Scale developed for the Turkish culture. Participants were asked to choose the items they believed represented their parents' practices. Thus, each subject had a score ranging from 0 to 12 in this scale. For means and standard deviations, see Table 1 . However, the reliability for this scale was rather low $(\alpha=.44)$.

\section{Procedure}

Questionnaires were distributed during class hours under the instructors' supervision. Respondents filled out the questionnaires anonymously. Average completion time was 20 minutes.

\section{Results}

The theoretical contrast between authoritarian and authoritative parenting styles was tested by correlating the scores of Turkish adolescents derived from their perceptions. Table 2 shows that there was indeed a negative and significant correlation between these two parenting styles $(r=-.38$, $p<.001)$.

Table 2

Inter-correlations between the scores of perceived parental authority $(n=401)$

\begin{tabular}{lcccc}
\hline & $\mathbf{1}$ & $\mathbf{2}$ & $\mathbf{3}$ & $\mathbf{4}$ \\
\hline $\begin{array}{l}\text { (1) Authoritarian } \\
\text { Parenting }\end{array}$ & - & $-.38^{* * *}$ & $-.33^{* * *}$ & $-.28^{* * *}$ \\
$\begin{array}{l}\text { (2) Authoritative } \\
\text { Parenting }\end{array}$ & & & & \\
$\begin{array}{l}\text { (3) Psychological } \\
\text { Involvement }\end{array}$ & & & & $.83^{* * *}$ \\
\hline
\end{tabular}

(4) Autonomy Granting

${ }^{*} p<.05 ;{ }^{* *} p<.01 ;{ }^{* * *} p<.001$ (one-tailed).

Given the low reliability coefficient for the authoritarian parenting scale, this negative correlation between contrasting parenting practices is encouraging in terms of the validity of the other results related to the analyses of the scores derived from authoritarian parenting scale. Negative correlations between authoritarian parenting styles and sub-dimensions of authoritative parenting style (-.33 for PI and -.28 for $\mathrm{AG}, p<.001$ ), appoint to a different pattern from the one that Baumrind (1971) proposed for authoritarian parenting style that expects low autonomy but high psychological involvement. If one regards that authoritarian parenting practices in Eastern cultures can be described by limited verbal communication between children and parents, the adolescents in the sample perceives their parental practices as low PI. Thus these findings may be due to limited verbal communication between children and parents in the authoritarian parenting practices in Eastern cultures. The correlation between PI and AG was positive and significant $(r=.30, p<.001)$.
Parental education was significantly associated to adolescents' perceptions of their parents' practices with only one exception (Table 3). The directions of the correlations were the same for both mothers and fathers. Higher levels of parental education seem to favor family environment that can be characterized as authoritative family pattern (for mother's educational level, $r=.16, p<.01$; for father's educational level, $r=.21, p<.001$ ). Adolescents perceived their parents as more authoritarian as their parents' educational level decreased (for mother's educational level, $r=-.07, p>.05$; for father's educational level, $r=-.12, p<.001)$. Although the correlations were generally moderate, the pattern presented above is quite consistent with the expectations drawn from relevant literature. Given that the scores on parenting styles came from the perceptions of adolescents and that it is possible that such perceptions are vulnerable to different factors, the resultant picture is encouraging in terms of the validity of the scales used in the present study.

Table 3

Pearson correlation coefficients between parental education and the scores of perceived parental authority $(n=401)$

\begin{tabular}{lcc}
\hline & $\begin{array}{c}\text { Mother's } \\
\text { Educational } \\
\text { Level }\end{array}$ & $\begin{array}{c}\text { Father's } \\
\text { Educational } \\
\text { Level }\end{array}$ \\
\hline $\begin{array}{l}\text { Authoritarian } \\
\text { Parenting } \\
\text { Authoritative }\end{array}$ & -.07 & $-.12^{* *}$ \\
$\begin{array}{l}\text { Parenting } \\
\text { Psychological }\end{array}$ & $.16^{* * *}$ & $.21^{* * *}$ \\
$\begin{array}{l}\text { Involvement } \\
\text { Autonomy Granting }\end{array}$ & $.12^{*}$ & $.14^{* *}$ \\
${ }^{*} p<.05 ;{ }^{* *} p<.01 ;{ }^{* * *} p<.001$ (one-tailed). & $.18^{* * *}$ \\
\end{tabular}

The intercorrelations between four identity styles were generally consistent with the expectations stated in Berzonsky's model (Table 4). The exception to the model was a small, but positive and significant correlation between normative and informational styles $(r=.09, p<.05)$. Informational style correlated positively with identity commitment style $(r=.30, p<.001)$, whereas its correlation with diffuse/avoidant style was negative $(r=-.27, p<.001)$. As can be expected, diffuse/avoidant style associated negatively with other identity styles. Identity commitment styles correlated positively with normative style $(r=.41, p<.001)$.

Table 4

Inter-correlations between Berzonsky's four identity statuses $(n=401)$

\begin{tabular}{lcccc}
\hline & $\mathbf{1}$ & $\mathbf{2}$ & $\mathbf{3}$ & $\mathbf{4}$ \\
\hline (1) Informational & - & $.09^{*}$ & $-.27^{* * *}$ & $.30^{* * *}$ \\
(2) Normative & & - & $-.12^{* *}$ & $.41^{* * *}$ \\
(3) Diffuse/Avoidant & & & - & $-.28^{* * *}$ \\
(4) Identity & & & - \\
Commitment & & & - \\
${ }^{*} p<.05 ;{ }^{* *} p<.01 ; * * * p<.001$ (one-tailed). & & &
\end{tabular}


Table 5 presents the results of the hierarchical regression analysis of the scores of the identity commitment style. Gender, used as control variable, appeared as significant predictor of this identity style $(\beta=-.13, p<.01)$; females were more likely to give higher importance to this identity style than males.

Table 5

Identity scores regressed hierarchically on gender, parental education, perceived parental authority, and identity style variables

\begin{tabular}{|c|c|c|c|c|c|}
\hline & Step 1 Beta & Step 2 Beta & Step 3 Beta & Step 4 Beta & Step 5 Beta \\
\hline Gendera & $-.13^{* *}$ & $-.13^{* *}$ & $-.10^{*}$ & -.08 & -.10 \\
\hline Mother's Education ${ }^{\mathrm{b}}$ & & -.03 & -.04 & -.02 & -.01 \\
\hline Father's Education ${ }^{\mathrm{c}}$ & & .05 & .00 & .05 & .06 \\
\hline Authoritarian Parenting & & & .02 & -.04 & .05 \\
\hline Psychological Involvement & & & $.22^{* * *}$ & .05 & .06 \\
\hline Autonomy Granting & & & $.14^{* *}$ & $.11^{*}$ & $.15^{*}$ \\
\hline Informational & & & & $.21^{* * *}$ & $.24^{* * *}$ \\
\hline Normative & & & & $.36^{* * *}$ & $.26^{* * *}$ \\
\hline Diffuse/Avoidant & & & & $-.15^{* *}$ & -.13 \\
\hline Gender X Normative & & & & & $.80^{*}$ \\
\hline Variance Explained (R2) & $.018^{* *}$ & .02 & $.10^{* * *}$ & $.30^{* * *}$ & $.32^{* * *}$ \\
\hline R2 Change & $.018^{* *}$ & .002 & $.08^{* * *}$ & $.21^{* * *}$ & .02 \\
\hline
\end{tabular}

Despite significant associations between parental education and adolescents' perceptions of parenting styles presented above, the educational levels of parents could not predict the identity commitment scores of adolescents (change in $R^{2}=.002, p>.05$ ). Two sub-dimensions of authoritative parenting appeared as significant predictors of this identity style (for PI, $\beta=.22, p<.001$; for $\mathrm{AG}, \beta=.14, p<.01$ ); adolescents' scores on identity commitment style increased as they perceived their parents' practices as authoritative. On the other hand, authoritarian parenting style could not explain significant variance in identity commitment scores $(\beta=.02, p>.05)$.

Entering other three identity styles led to a significant increase in the explained variance (change in $R^{2}=.21$, $p<.001$ ). When examined separately, the findings showed that identity commitment style positively associates with informational and normative styles ( $\beta$ 's, .21 and .36, respectively, $p<.001)$ and negatively with diffuse/avoidant style $(\beta=-.15, p<.01)$. These findings support Berzonsky's theoretical model. Only one of the interaction terms that were entered in the regression equation in the last step was significant: the interaction between gender and normative style predicted significant variance $(\beta=.80, p<.05)$, showing that males tend to use a more norm-oriented strategy when exhibiting identity commitment than females. This finding is consistent with the finding on the effect of gender on identity commitment styles showing that females were more likely to use this style.

Other three identity styles were separately regressed on gender, parental education, and parental authority variables (Table 6). The results show that gender variable predicted significant variance only in the scores of diffuse/avoidant style $\left(\beta=.23, p<.001 ; R^{2}=.06, p<.001\right)$; compared to females, males tend to use this style more. This set of findings regarding the gender effect is consistent with Berzonsky's (1993) findings. The variables of parental education that were entered in the equation in the second step did not predict any significant variance. 
Table 6

Identity style regressed hierarchically on gender, parental education, and perceived parental authority

\begin{tabular}{|c|c|c|c|}
\hline & $\begin{array}{c}\text { Step } 1 \\
\text { Beta }\end{array}$ & $\begin{array}{c}\text { Step } 2 \\
\text { Beta }\end{array}$ & $\begin{array}{r}\text { Step } 3 \\
\text { Beta }\end{array}$ \\
\hline \multicolumn{4}{|l|}{ DV: Informational Style } \\
\hline Gendera & -.05 & -.05 & -.04 \\
\hline Mother's Education ${ }^{\mathrm{b}}$ & & .01 & .01 \\
\hline Father's Education ${ }^{\mathrm{c}}$ & & -.02 & -.05 \\
\hline Authoritarian Parenting & & & $.15^{* *}$ \\
\hline $\begin{array}{l}\text { Psychological } \\
\text { Involvement }\end{array}$ & & & $.21^{* * *}$ \\
\hline Autonomy Granting & & & $.08^{* *}$ \\
\hline Variance Explained $\left(\mathrm{R}^{2}\right)$ & .00 & .00 & $.06^{* *}$ \\
\hline R2 Change & .00 & .00 & $.06^{* * *}$ \\
\hline \multicolumn{4}{|l|}{ DV: Normative Style } \\
\hline Gendera & .02 & .01 & .05 \\
\hline Mother's Education ${ }^{\mathrm{b}}$ & & -.07 & -.07 \\
\hline Father's Education ${ }^{c}$ & & -.06 & -.11 \\
\hline Authoritarian Parenting & & & .05 \\
\hline $\begin{array}{l}\text { Psychological } \\
\text { Involvement }\end{array}$ & & & $.29^{* * *}$ \\
\hline Autonomy Granting & & & -.01 \\
\hline Variance Explained $\left(\mathrm{R}^{2}\right)$ & .00 & .02 & $.09^{* * *}$ \\
\hline $\mathrm{R}^{2}$ Change & .00 & .02 & $.07^{* * *}$ \\
\hline \multicolumn{4}{|l|}{$\begin{array}{l}\text { DV: Diffuse/Avoidant } \\
\text { Style }\end{array}$} \\
\hline Gendera & $.23^{* * *}$ & $.23^{* * *}$ & $.22^{* * *}$ \\
\hline Mother's Education ${ }^{\mathrm{b}}$ & & .02 & .03 \\
\hline Father's Education ${ }^{c}$ & & -.03 & .01 \\
\hline Authoritarian Parenting & & & -.05 \\
\hline $\begin{array}{l}\text { Psychological } \\
\text { Involvement }\end{array}$ & & & $-.13^{*}$ \\
\hline Autonomy Granting & & & $-.11^{*}$ \\
\hline Variance Explained $\left(\mathrm{R}^{2}\right)$ & $.06^{* * *}$ & $.06^{* * *}$ & $.09^{* * *}$ \\
\hline $\mathrm{R}^{2}$ Change & $.06^{* * *}$ & .00 & $.03^{* *}$ \\
\hline
\end{tabular}

${ }^{*} p<.05 ;{ }^{* *} p<.01 ;{ }^{* * *} p<.001$

a Gender: Female $=0$; Male $=1$.

b, c Educational Level: 1=Primary; 2=Secondary; 3=High school; 4=University.

The finding related to adolescents' perceptions of their parents' practices yielded a somewhat different picture from that presented by the findings of the Berzonsky's study. Contrary to expectations, authoritarian parenting style could predict only the scores of the informational identity style $(\beta=.15, p<.01)$. This parenting style did not predict any significant variance in the scores of normative and diffuse/ avoidant styles (Beta's, .05 and -.05, respectively, $p>.05$ ). The results from the sub-dimensions of the authoritative parenting style (PI and AG), on the other hand, were more consistent with expectations: both of these two dimensions could predict informational styles (for PI, $\beta=.15 p<.01$; for AG, $\beta=.21, p<.001$ ), showing that as PI and AG increased, adolescents tended to give more importance to the informational style items. On the other hand, normative style was associated only with PI dimension $(\beta=.29, p<.001)$; normative style seems to be more likely as the psychological involvement of parents increase. The effects of PI and AG on diffuse/avoidant style were in line with theoretical expectations (for PI, $\beta=-.13, p<.05$; for $\mathrm{AG}, \beta=.11, p<.05$ ); adolescents tend to give more importance to diffuse/avoidant style as the amount of psychological involvement of parents and the level of autonomy granted decrease.

\section{Discussion}

This study aimed to show the relationship between child-rearing styles (authoritarian, authoritative) and socio-cognitive identity styles (informational, normative, diffuse/avoidant and identity commitment). The sample's age distribution is 17 to 26 years of age. As the age group chosen for this study represents the period in which identity is crystallized. Especially Erikson accepted this period as crystallized identity (Adams \& Jones, 1983; Muuss, 1996), the effect of age variable is not considered in this study. Instead, by considering that parent's child-rearing systems or socialization would be perceived differently by gender groups, the gender variable was included in the analysis. We also assumed that the permissive child-rearing system is rarely seen in Turkey. Therefore, only the authoritarian and authoritative family patterns were included in the analyses. Additionally, parents' educational level, which was thought to have a direct effect on child-rearing system, was also included in the study. Therefore, individual differences, which are the outcomes of cultural norms and educational level, were expected to be present.

Our results showed that there is a positive relationship between informational, normative, and identity commitment styles, whereas the relationship between commitment and diffused/avoidant styles is negative. These findings are quite similar to those found by Berzonsky (Berzonsky \& Kinney, 1998). When these results are evaluated in relation to Marcia's identity statuses, there is a commitment in both normative and informational identity styles. In general, our findings provide some support for Berzonsky's theoretical framework.

However, the finding showing a positive relationship between the normative and information exploration styles contradicts to both Marcia's (1966) and Berzonsky's (1992a) findings. There are two explanations for this contradictory finding. Firstly, the sample is homogeneous as it is comprised 
of university freshmen. Since a certain level of information exploration is needed in order to enter university (e.g. entrance exams), importance given to the informational identity style is not unexpected. Mean scores of the sample are in conformity with our claim: informational identity takes place just after the commitment style in hierarchy (commitment, $X=3.82, S D=.47$; informational, $X=3.70$, $S D=.50$; normative style $X=3.52, S D=.51$; diffuse-avoidant identity style, $X=2.34, S D=.64)$. As can be expected, the diffuse/avoidant identity style appeared at the bottom of this list. Norm-oriented adolescents, in special, give importance to active information exploration because they have problems in acquiring direct knowledge from their reference group (family, relatives). This explains the positive correlation between scores of normative identity and scores of informational identity styles. From this point of view, negative correlations between the scores of diffuse/avoidant and informational identity styles are expected and the results support these expectations.

Additional evidence for our argument comes from the correlations between normative identity style and parents' educational level, (for mother's education level: $r=-.13$, $p<.01$; for fathers education level; $r=-.15, p<.01$ ). These correlations show that as the level of education decreases, scores of normative identity style increase. That means norm-oriented adolescents have some difficulty in getting direct help, for future plans, from their parents. Thus, they actively seek for proper information.

The second explanation is related to the sensibility of theoretical differentiation within four identity styles in Turkish culture. The studies that have been carried out in Western societies show contradictory results related to normative identity style. It seems that Western theories do not consider the variations in socio-economic context when they are constructing the model for an individual. Therefore, the Western models have some difficulty in explaining individuals who live in countries like Turkey, which is going through rapid changes and presents high mobility (Aksit, 2007; Kağıtçıbaş1, 2005). Unfortunately, as identity studies in Turkey have not used the factor analysis method for checking the validity of mainstream measures (Eryüksel, 1987), it is not possible to compare the results of this study with the results of previous studies. However, cultural influences on identity development can easily be seen in gender differences, which are obtained in this study. The results of the multiple regression analyses of commitment identity style show that gender differences predict the scores for the identity commitment style (Table 5). Compared to male adolescents, female adolescents tend to have commitmentoriented identity styles more. These results do not fit into Berzonsky's model. This can be explained by cultural differences in socialization practices. In Turkish society, there is a tendency to give more opportunities to females, especially to those who live in urban areas and middle SES (Socio Economic Status) families (Gavas, 1998).
Our findings point to the importance of psychological involvement and autonomy in the process of developing commitment identity style. It would be easier to understand commitment if we relate it with norm-oriented and information-oriented identity styles. The studies of Marcia (1966) and Matteson (1977) help us to explain the situation. These researchers report that parents of female adolescents are psychologically involved and regulate their behavior, but do not support autonomy and independence. This parenting style does not help the youth to perform a self-exploration. In this study, psychological involvement and autonomy scores predicted commitment identity style, showing that commitment identity of female adolescents may be related to information-oriented identity style.

Several identity studies (Josselson, 1987; LaVoie, 1976) argue that different socialization processes (i.e. parents' child-rearing style) may lead to different identity styles. Several developmentalists also insist that warm, welcoming and supporting parents would raise children with positive identity styles (Adams \& Jones, 1983). Gavas (1998) reports that Turkish female adolescents have more opportunities to explore compared to male adolescents. Celen and Cok (2000) reported that there is an increase in autonomy of both female and male adolescents, and Turkish parents tend to give more autonomy to their children. However, other Turkish researchers (Dereboy, Dereboy, Sevincok, \& Kaynak, 1999; Eryüksel, 1987; Köker, 1997; Varan, 1990) did not reach the same results. This result is in disagreement with Berzonsky's (1993) findings. Given the persistent predictive power of gender, even after controlling the effects of parental education and perceptions of parenting style, this finding seems to point to a cultural difference in identity development process in terms of gender effects.

Results of the present study show that male adolescents have high commitment scores, but they are more normoriented. This means that they adopt norms of prestigious models without any exploration. D'Andrade (1974) reports that dominant fathers (traditional way of parenting) restrict achievement tendencies and autonomous behavior of male adolescents. Clelland (1961) also reported similar results in Japan, Brazil and Germany (as cited by, Bradburn, 1963). Bradburn (1963) showed that autocratic Turkish fathers restrict male adolescents' achievement tendency, but these findings are contradictory to those found in Celen and Cok's (2000) and Hortacsu, Oral and Yasak-Gultekin's (1991) studies.

The gender variable plays a role in developing diffuse/ avoidant identity style. Various high valued expectations directed to male adolescents may create a tension that leads to a diffuse/avoidant identity style. There is an indirect relationship between the educational level of parents and identity style. Although, the results of the regression analyses did not show any relationship between these scores, significant correlations between education variable and authoritative parenting style pointed out that increased educational level leads to authoritative parenting style (Table 5). 
Although Adams and Berzonsky (2003) and others state there is a relationship between information-oriented identity style and authoritative parenting, the present study's findings showed that there is a positive correlation between norm-oriented and information-oriented scores in the study. Adolescents who live with authoritarian parents also acquire informational identity style. This kind of parenting style has been considered as "pathological" by Western psychologists, but others argue that this may not be the case in Eastern cultures (Kağıtçıbaşı, 1996a). Psychological outcomes of authoritarian parenting styles are not same in all contexts. For example, Mead (1970) named societies that are going under rapid changes as "pre-figurative" and reported that characteristics of norm-oriented identity styles may be intertwined in these conditions.

In general, authoritative parenting style predicted four identity styles in an expected way. Higher levels of authoritative style are related to higher scores for commitment and informational identity styles and lower levels of authoritative style are related to higher scores for norm-oriented and diffuse/avoidant identity styles.

\section{Conclusion}

There is evidence (Chao, 1994) showing that authoritarian parenting practices need not to be perceived by adolescents as disturbingly strict to Eastern cultures, where such a parenting style is considered as a widely accepted norm. Therefore, the models developed in mainstream psychology do not easily fit into the findings originated in Eastern cultures (Steward, Bond, Deeds, Westrict, \& Chung, 1999). The findings of this study, related to the authoritative parenting style, seem to provide some insight to the problems that reside in the authoritarian parenting concept. Compared to authoritarian parenting styles, the authoritative parenting style could predict more significant variance in all of the scores of the four identity styles in expected directions. The tendency of adolescents in promoting identity commitment and informational styles increased with high levels of authoritativeness in family environment, whereas adolescents who live in a less authoritative family environment tend to give high importance to normative and diffuse/avoidant styles. According to Kağıtçıbaşı (1996b), authoritarian parenting style characterizes more traditional, rural/agrarian contexts, where sons are considered as more valuable than daughters because of their potential economic contribution to the family, whereas families in economically more developed/urban context, tend to use an authoritative parenting style in order to deal with the demands of a rapidly changing environment, consequently value girls as well. The sample of this study included adolescents from families with rather educated parents. Therefore, the lack of the predictive power of authoritarian parenting style in the present study may be a result of the sample nature.

Kağıtçıbaşı (1996a, 2005) proposes a solution to problems that arise from the apparent diversity of the effects of socioeconomic factors on parenting practices and their perceptions by children within and between cultures analyses. According to her, instead of producing parenting typologies that may be culturally biased, taking autonomy as a continuum ranging from high to low autonomy granted to children by families, would produce more objective measures of parental authority. Steinberg's two-dimensional model provides the possibility of measuring the two important components of parenting, namely, PI and AG. When viewed under the light of this model, findings present a meaningful pattern: informational and identity commitment styles are associated with perceptions of high levels of PI and AG, whereas adolescents who gave higher importance to diffuse/ avoidant style perceived their parents as insufficient in terms of psychological involvement and autonomy level they grant. Normative style, on the other hand, was associated with high levels of PI and low levels of AG. Drawing upon the findings of the present study, Figure 1 presents possible effects of parenting practices on identity development process using Steinberg's dimensions of high-low PI and high-low AG.

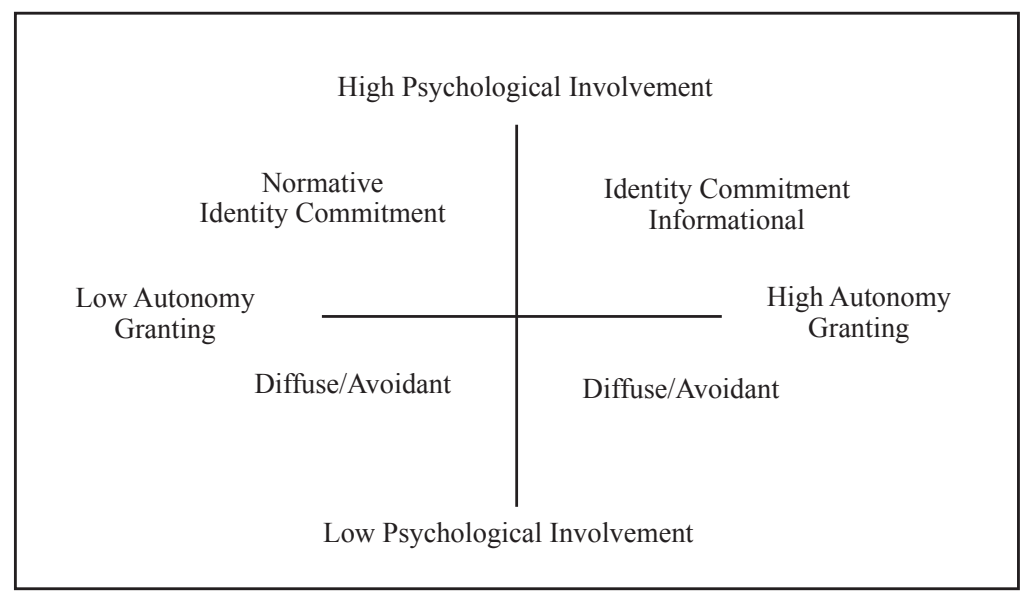

Figure 1. The relationships between Berzonsky's four identity styles and Steinberg's dimensions of psychological involvement and autonomy granting. 
Thus, the pattern of high PI-high AG can be expected to lead to identity commitment and informational styles, whereas normative and identity commitment can be regarded as possible outcomes of high PI-low AG, taking into account gender and personality differences. The pattern characterized by low PI-high AG can be regarded as an equivalent of Baumrind's (1971) "permissive" parenting style and is expected to lead to diffuse/avoidant identity style. Finally, the pattern of low PI-low AG is expected to increase the possibility of diffuse/avoidant identity. This pattern can be regarded as conceptual equivalent to Baumrind's "authoritarian" parenting style. However, fourfold typology presented here allows for variations in different cultural contexts. Therefore, it seems more feasible to search for such models that do not depend on biased constructs like "authoritarian" parenting style.

\section{References}

Adams, G. R., \& Berzonsky, M. (Eds.). (2003). The blackwell handbook on adolescence. Oxford, UK: Blackwell Publication.

Adams, G. R., \& Jones, R. M. (1983). Female adolescent identity development age comparisons and perceived child rearing practice. Developmental Psychology, 19, 249-257.

Aksit, B. T. (Ed.). (2007). Population and development strategies and political suggestions for Turkey. Ankara: The Turkish Academy of Science.

Baumrind, D. (1971). Current patterns of parental authority. Developmental Psychology Monographs, 4, 1-103.

Baumrind, D. (1991a). Parenting styles and adolescent development. In R. M. Lerner, A. C. Peterson, \& J. Brooks-Gunn (Eds.), Encyclopedia of adolescence (pp. 746-758). New York: Garland.

Baumrind, D. (1991b). The influence of parenting style on adolescent competence and substance use. Journal of Early Adolescence, 11, 56-95.

Berzonsky, M. D. (1992a). Identity and stress management. In G. R. Adams, T. P. Gullotto, \& R. Montemayor (Eds.), Adolescent identity formation: Vol. 4. (pp. 193-216). Newbury Park, CA: Sage.

Berzonsky, M. D. (1992b). Identity style and coping strategies. Journal of Personality, 60, 771-788.

Berzonsky, M. D. (1993). Identity style, gender and socialcognitive reasoning. Journal of Adolescent Research, 8, 289-296.

Berzonsky, M. D., \& Kuk, L. D. (2000). Identity status, identity processing style and transition to university. Journal of Adolescent Research, 15, 81-98.

Berzonsky, M. D., \& Kinney, A. (1998). Identity commitment, identity style and parental authority. Paper presented at the Biennial Meeting of Society for Research on Adolescence, San Diego, CA.
Berzonsky, M. D., \& Sullivan, C. (1992). Social and cognitive aspects of identity style: Need for cognition, experiential openness and introspection. Journal of Adolescent Research, 7, 140-155.

Bosma, H. (1992). Identity in adolescence: Managing commitments. In G. R. Adams, T. P. Gullotta, \& R. Montemayor (Eds.), Adolescent identity formation (pp. 91-121). Newbury Park, CA: Sage.

Bradburn, N. M. (1963). N-achievement and father dominance in Turkey. Journal of Abnormal and Social Psychology, 67, 464-468.

Celen, N., \& Cok, F. (2000). Decisional autonomy of Turkish adolescent [Abstract]. Biennial Conference of European Adolescent Research Association Conference, 7.

Chao, R. K. (1994). Beyond parental control and authoritarian parenting style: Understanding Chinese parenting through the cultural notion of training. Child Development, 65, 1111-1119.

D’Andrade, R. G. (1974). Sex differences and cultural institutions. In R. A. Levine(Ed.), Culture and personality: Contemporary readings. Chicago, IL: Aldne.

Dereboy, F., Dereboy, C., Sevincok, L., \& Kaynak, H. (1999). Gençlerde kimlik gelişimi sürecini değerlendirmede kullanılan iki ölçeğin psikometrik özellikleri [Psychometric characteristics of two different identity measures]. Türk Psikiatri Dergisi [Turkish Journal of Psychiatry], 10, 92-101.

Duvall, S., \& Wichlund, R. A. (1972). A theory of objective self-awareness. Orlando, FL: Academic Press.

Enright, R. D., \& Deist, D. M. (1979). Social perspective taking as a component of identity formation. Adolescence, 14, 517-522.

Erikson, E. (1950). The problem of ego identity. Journal of American Psychoanalytic Association, 4, 56-121.

Erikson, E. (1968). Identity, youth and crisis. New York: Norton.

Eryüksel, G. N. (1987). Ergenlerde kimlik statülerini incelemeye ilişkin kesitsel bir çalışma [A cross-sectional study on adolescents' identity development]. Unpublished master's thesis, Hacettepe University, Ankara, Turkey.

Gavas, A. (1998). Kimlik gelişimi sirasında ergenin aile ilişkilerinin saptanması [An examination of adolescent's family relationship in the process of identity development]. Unpublished master's thesis, Uludag University, Bursa, Turkey.

Hart, D., Maloney, A., \& Damon, W. (1987). The meaning and development of identity. In T. Honess \& K. Yardley (Eds.), Self and identity perspectives across lifespan. London: Routledge.

Hortacsu, N., Oral, A., \& Yasak-Gultekin, Y. (1991). Factors affecting relationship of Turkish adolescents with parents and same sex friends. Journal of Social Psychology, 131, 413-426. 
Josselson, R. (1987). Pathways to identity development in woman. San Francisco: Jossey-Bass.

Kağıtçıbaşı, Ç. (1996a). Family and human development across cultures. New York: Lawrence Erlbaum.

Kağıtçıbaşı, Ç. (1996b). The autonomous-relational self: A new synthesis. European Psychologist, 1, 180-186.

Kağıtçıbaşı, Ç. (2005). Autonomy and relatedness in cultural context. Journal of Cross Cultural Psychology, 36, 1-20.

Köker, S. (1997). Kimlik duygusunun kazanılması açısından ergenlerin, genç yetişkinlerin, yetişkinlerin karşılaştırılması [Comparison of adolescents, young adults and adults in terms of identity development]. Unpublished $\mathrm{PhD}$ thesis, Ankara University, Ankara, Turkey.

Lamborn, S., Mounts, N., Steinberg, L., \& Dornbusch, S. M. (1991). Patterns of competence and adjustment among adolescents from authoritative and authoritarian indulgent and neglected families. Child Development, 62, 1049-1063.

LaVoie, J. C. (1976). Ego identity formation in middle adolescence. Journal of Youth and Adolescence, 5, 371385.

Marcia, J. (1966). Development and validation of ego identity status. Journal of Personality and Social Psychology, 3, 551-558.

Matteson, D. R. (1977). Exploration and commitment: Sex differences and methodological problems in the use of identity status categories. Journal of Youth and Adolescence, 6, 353-374.

Mead, M. (1970). Culture and commitment: A study of generation gap. New York: Doubleday.

Muuss, R. E. (1996). Theories of adolescence. New York: The McGraw Hill.

Rowe, I., \& Marcia, J. E. (1980). Ego identity status, formal operations and moral development. Journal of Youth and Adolescence, 9, 87-99.

Shaffer, D. R. (1994). Social and personality development. New York: Brooks \& Cole.

Steinberg, L., Elmen, J., \& Mounts, N. S. (1989). Authoritative parenting, psycho-social maturity, and academic success among adolescents. Child Development, 60, 1424-1436.

Steinberg, L., \& Hill, J. (1978). Patterns of family interaction as a function of age, the onset of puberty and formal thinking. Developmental Psychology, 14, 674-683.

Stewart, S. M., Bond, M. H., Deeds, O., Westrict, J., \& Chung, S. F. (1999). Intergenerational patterns of values and autonomy expectations in cultures of relatedness and separateness. Journal of Cross-Cultural Psychology, 30, 14-32

Varan, A. (1990). Liseli gençlerde kimlik statülerinin cinsiyet, yaş, ve sosyal çevre açısından incelenmesi. [An examination of identity statutes of high school students in relation with age, gender and social context]. Unpublished $\mathrm{PhD}$ thesis, Hacettepe University, Ankara, Turkey.
Hacer Nermin Çelen is Professor of Maltepe University, Istanbul, Turkey.

Muharrem Ersin Kuşdil is Associate Professor of Uludag University, Bursa, Turkey.
Recebido: 29/02/2008

$1^{a}$ revisão: 04/09/2008

Aceite final: 17/12/2008 